This is a pre-copyedited, author-produced version of an article accepted for publication in Environment and Planning D: Society and Space following peer review.

\title{
Making kinship with human remains: repatriation, biomedicine and the many relations of Charles Byrne
}

Catherine Nash, Queen Mary University of London

This paper is about a skeleton, arguments about where it should be, and the different models of relatedness that are mobilised to give them moral legitimacy. The articulated skeleton and skull are the remains of Charles Byrne, popularly known as the 'Irish Giant', who was born in Co. Tyrone in what is now Northern Ireland in 1761 and who died in London in 1783. The remains have been on display in the Hunterian Museum at the Royal College of Surgeons (RCS) as an example of gigantism since the early nineteenth century. They were acquired by the surgeon John Hunter and prepared for study and display, against the wishes of the deceased. Over the last ten years requests have been made to remove them from display and for their burial. Public interest in the case reflects wider awareness of the repatriation of human remains in European museums to indigenous communities, and more specifically, news of the genetic analysis of the remains in 2011 and subsequent biomedical research. National and international controversies regarding the treatment of human remains and subsequent legislation have also shaped museological approaches and public interest in this case. ${ }^{1}$

More broadly, this is a paper about the making of kinship with human remains. By this I mean the ways in which human remains may be used as materials through which genealogical, ancestral and wider forms of relatedness are produced, both in terms of direct relatedness to the deceased and in terms of wider categories of belonging. In their exploration of the 'emotive and affective potency of bone' Cara Krmpotich, Joost Fontein and John Harris advocate attentiveness to 'what bones, enable, afford, provoke, constrain or allow' (2010: 373). They argue that 'it is bones that affirm kinship relations and memory' (2010: 375). For them, 'kinship grown out of biology, time and (most often) nurturance, as well as relatedness grown out of shared landscapes (Ingold, 2000), come 
to the fore as lenses through which immediate and individualized responses to bones should be understood' (2010: 375). In this paper, I similarly consider kinship both in terms of genealogical or biological relationships and as continuously made in practice in immediate social relations. However, I expand its meaning beyond the immediate and individualised' to include wider geographies of relatedness through shared descent that are implicated in categories of nation, ethnicity and race, whose language of genealogical closeness and distance is entangled with imaginative geographies of cultural proximity, purity, diversity and difference (Nash 2005a; 2015).

Bones, and human remains more widely, are potent materials in on-going relationships between the living and dead. The ways in which human remains are given value, treated and moved, also express and enact relations among the living (Hallam 2010; Hallam and Hockey 2001; Hallam, Hockey and Howarth 1999; Young and Light 2013; Verdery 1999). Relatedness to the deceased is key to who is deemed to have moral authority to determine how their remains should be treated and where the remains should be. But what forms of relatedness are prioritised and enacted through human remains and how do they express and naturalise wider social relations? In this case, the remains of Charles Byrne are not those of a recently deceased person survived by those who mourn him. Nor do they represent a distant unnamed ancestor to be honoured through the appropriate treatment of their remains, as is predominantly the case in the repatriation of indigenous remains (Fforde and Hubert 2006; Turnbull and Pickering 2010). As far as is known through historical records, Charles Byrne had no descendants. Thus in a strictly genealogical sense of direct descent he is no one's ancestor. There are no descendants to speak for him and authorise a resting place for his remains. This would be irrelevant if his sufficiently well documented wishes for burial were respected (Charlier 2104). But given the refusal of the RCS to so do, relations to him and categories of relatedness are being made and mobilised in campaigns to have his remains removed from display and buried.

Exploring how these geographies of relatedness are both mobilised and produced through the imaginative identification with and incorporation of Charles Byrne into different communities of relatedness is a means through which to address the cultural potency of ideas of ancestral origins and ancestral relatedness in relation to geographies of belonging at different scales. This thus extends understandings of 'dead body politics' by exploring not the overtly politicised mobilisation of the dead bodies of kin in the 
making of states as national genealogical communities (Verdery 1999) but the making of kinship to and with the remains in relation to national and other geographies of identity in, what I argue is, a intersecting postcolonial geography of repatriation. Kinship to the dead is not given in this case. Instead, relations are being made through the familiar yet potent idiom of shared ancestry, both broadly evoked and scientifically explored.

Kinship is being made through the biomedical analysis of the remains and the way the results of the analysis have been deployed by the Hunterian Museum. The extraction and analysis of genetic material from the remains of Charles Byrne reflects the increasing interests of geneticists in investigating the genomics of old or ancient human remains. Genomic accounts of patterns of human relatedness and the associated culture and commerce of genetic genealogy over the last two decades have largely depended on the analysis of genetic material from living individuals from selected 'populations'. This has been used to infer ancestral relations with historical figures as well as broader genealogical lineages and ancestral locations (Nash 2015). As technological advances have made it easier to extract DNA from ancient hominid and human remains, genetic material from ancient and more modern human remains has been analysed to explore what it may suggest about human evolution, the individual themselves, or about patterns of kinship among those whose ancient human remains survive, to infer their degree of genetic difference from a contemporary population, or to identify living descendants (Johnson and Paul 2016; Slatkin and Racimo 2016). In this case, a study of ancestral connections among those sharing a genetically inherited condition and to Charles Byrne through the analysis of DNA extracted from his skeletal material (Chahal et al 2011), has, as I will argue, produced a new relation.

In this paper I explore how kinship is enacted and affirmed in the biomedical and discursive treatment of the remains of Charles Byrne, in the absence of a genealogically close, near or direct descendant or clear claimant community who would count as close kin and thus speak for him. I trace this in the records of requests for reburial submitted and responded to by the RCS; the biomedical study of ancestral relatedness to Charles Byrne and among a regionally specific group of patients; legal and scientific arguments about the remains; popular campaigns, wider media reporting and recent documentaries about the case. I begin by considering the question of kinship with and through human remains, before addressing how the remains of Byrne are mobilised in the making of ideas of national, regional and local belonging for the remains themselves and for 
differently imagined geographies of relatedness and collective identity. I then turn to the recent biomedical and social production of genetic relatedness.

\section{Kinship with human remains}

Kinship is profoundly significant to the meaning and treatment of human remains, albeit in multiple and complex ways. Most broadly, in contemporary medical, legal and museology contexts determining respectful and appropriate treatment of human remains is deeply bound up with an ethics of respecting the wishes of those people who have the closest kinship relation to the deceased (McGuinness and Brazier 2008). This is whether they are the 'next of kin' of a recently deceased individual, conventionally defined in terms of familial relations of marriage, birth and parentage, or a wider community to whom the deceased individual belongs as part of an ancestral group. The reckoning of close kinship is also at work in how models of collective identity and relatedness are figured in terms of the temporal depth of extended kinship relations within groups. Ancestral connections over many generations and immediate kinship both constitute close relatedness.

Kinship, both relatively recent, direct and proximate, and extended, collective and genealogically deep, is recognised and negotiated in the repatriation policy of European museums and scientific institutions holding human remains. Being closely related or having a broad ancestral connection to the individual whose remains are held in European museums is central to the contemporary legal regulation of requests for their burial or repatriation. This is reflected in the RCS Museum and Archives Acquisition and Disposal Policy which states that:

6.4 So far as human material derived from named individuals is concerned the College will consider requests for its return received from close relatives sympathetically, on a case-by-case basis, provided that:

6.4.1 They can furnish legal evidence of the relationship

6.4.2 The wishes of the named individuals are not contravened (RCS, 2013a, 7)

There is a specific policy on the return of human remains of non-European indigenous peoples for which accurate geographical provenance exists. These requests for return: 
will be considered on a case by case basis, provided that:

6.7.1 The request originates from a representative body recognised as such under relevant regional, state or national legislation covering the return of human remains.

6.7.2 Ownership of the remains is not contested between two or more recognised representative bodies. (RCS, 2013a, 7.)

In the case of unnamed indigenous remains, 'accurate geographical provenance' stands in for a known genealogical connection between a deceased unnamed individual and a contemporary indigenous community, thus allowing for the appropriate recognition of the deceased's place in the broader ancestral group of the community. The rights of close relatives or the broad descent group are based on the idea of genealogical relatedness as a meaningful category of social relations between living people and between living people and their ancestors, which naturalises the claims, interests or rights of particular people to determine what should happen to the remains of their relatives.

In this sense, kinship inheres in the remains themselves. If the deceased individual is not known by name there is the possibility of using the remains as sources of evidence about both the identity of the individual (through dental records for example) and their identity in relation to others (as mother, sister, son etc.). In forensic genetics biogenetic kinship is understood to inhere in the remains and to be scientifically ascertained through the forensic and genomic analysis of unnamed human remains in comparison to the genomics of potential family members to establish their relation and thus identity.. Kinship in this sense is taken to be a biogenetic relation, evident in the inheritance of genomic material from parents to progeny or wider patterns of genetic similarity that are taken to indicate shared ancestry.

This may be reasonably straightforward in the case of close relatives and is profoundly important to dealing with the loss of family members who are victims of abduction, murder or mass killing in contexts of civil or state violence. However, biogenetic versions of kinship that are integral to forensic genomics may privilege some forms of relation over others, for example, in the relative marginalisation of spouses in the public recognition of loss in comparison to the mothers of the disappeared in Argentina (Gandsman 2012). While the imperatives to identify the dead through forensic 
genetics in post-conflict contexts mean a necessary concentration on biogenetic kinship, bioarchaeologists are increasingly working to shift the focus from biological kinship to wider forms of relatedness in ancient family research (Johnson and Paul 2016).

Furthermore, the genomic identification of relatedness becomes more complex and more contingent in attempts to locate human remains and the individual they represent within broader collective categories since this involves identifying individuals in terms of genetic markers that are associated with 'populations' whose scientific codification reproduces and reinforces racialized regional categories of difference (Restrepo, Schwartz-Marín and Cárdenas 2014, 78-79). Indigenous groups negotiate the tension between the desire to honour ancestors through appropriate burial of repatriated remains and their resistance to their own genomic characterisation and to genomic determinations of relatedness in cases in which the specific geographical and community origins of indigenous remains cannot be identified in other ways (Morton, 2017).

Kinship can also be understood as both found within and made with human remains. Rather than simply or only existing before death or inhering within bones and uncovered through their analysis, kinship is also produced in practice through the care of human remains. Kinship shapes the significance of the remains of kin but is also produced through their treatment. The collective efforts of indigenous groups to repatriate the remains of ancestors from European museums can, as Cara Krmpotich (2010) argues, provide experiences through which ancestral and contemporary kinship relations can be enacted and affirmed. Though the meaning and effects of repatriation are in many cases complex and ambiguous (Morton, 2017), repatriation can be a way to remember, respect and care for ancestors, fulfil familial obligations, demonstrate appropriate familial care and respect for living kin, and connect kin through shared experiences that can be drawn on in 'constructions and affirmations of kinship relations in the present and with their ancestors' (Krmpotich, 2010, 175). Similarly, the exhumation of the dead in post-conflict contexts can both depend on the consent and cooperation of family members and entail the practice and negotiation of kinship in relation to wider collective identities and forms of commemoration (Caesar 2016).

Debates about the appropriate place for the remains of Charles Byrne can be considered both in light of this attentiveness to the making of kinship with and through human remains in the case of indigenous repatriation, and in terms of the interconnected and distinctive postcolonial geographies of this case. Debates about a resting place for the 
remains of an Irish 'giant' currently on display in an English anatomical museum are refracted through the practices and politics of the repatriation of human remains to indigenous communities. However, they also reflect the ways in which colonial discourses of difference continue to inflect the political and cultural relations between the United Kingdom and Ireland. In the rest of this paper I will first address how Charles Byrne himself and his remains have been figured as national and regional in origin in ways that emphasise ideas of ethnic difference and belonging and then turn to the biomedical making of relations.

\section{Relocating the remains}

Since Charles Byrne was a European individual and is known by name, a claim to having authority to determine where his remains should be would carry most weight if it were made by a direct descendant since they are most likely to count as a 'close relative'. There is no policy of devolving responsibility to a representative body in the case of claims to authority over the remains of named non-indigenous individuals held in British museums. Charles Byrne had no descendants, but he has lots of relatives. He has millions as a member of the global genealogical community of humanity sharing ancestry. But he can also be located within more differentiated and geographically delimited communities of shared descent - regional and national - some of which are being brought into being in new ways in arguments for but also against removing his remains from display and fulfil his wish to be buried at sea. His remains cannot be claimed as those of an ancestor but he is located within broader categories of relatedness at different geographical scales in efforts to relocate his remains.

The first scale is national. Calls for the burial of his remains vary in terms of whether they are explicit about where the remains should be interred, but many draw on ideas of the natural relations between soil, burial, ancestry, kinship and nationhood (Verdery 1999) to argue that they are currently displaced and that there is a national home for the remains and implicitly for Byrne. The remains are considered as in some sense the individual himself or containing or relating to his spirit. This is evident in the name of the Free Charles Byrne campaign by a relatively new group who describe him as an 'imprisoned Irish citizen', who evoke a national desire to bring back the bodies of 'our dead' soldiers and those imprisoned abroad in calling on the Irish diaspora to support the campaign: 
here's an imprisoned Irish citizen ignored by the governments of both Britain and Ireland. It will take The People's voice to demand justice for this forgotten soul. With millions of people around the World claiming Irish blood it's time we did something more positive with the power of the Diaspora.

(https://www.youtube.com/watch?v=QdPWNMstb0M Published on June 4, 2015)

These calls for reburial suggest that Byrne himself cannot be at rest since his remains are both exhibited and in exile.

However, the remains are nationalised not only in terms of an idea of a natural national resting place in response to the refusal to the museum to consider their relocation on the basis of the wishes of the deceased individual. They are nationalised through the way in which the Museum's resistance to their repatriation implies that origins matter in decisions about the treatment of human remains. For Michael Brennan, an Irish citizen living in Ireland, who pursued his request for the reburial of the remains of Charles Byrne in letters to the Hunterian Museum Trustees and to Irish and British state representatives most persistently in 2007-8, it was the impossibility of making a request for burial through a descendant that prompted him to articulate his concerns about the apparently differentiated treatment of the remains of someone of Irish origin compared to indigenous remains, and then more directly in terms of racial or ethnic discrimination. His initial concern about the remains of Byrne reflected his sense of their 'shared situation' of leaving Ireland as a young economic migrant to London, despite the very different historical context. This does not, as he knows, constitute a valid relation in repatriation. Instead, he turned to a stronger argument for reburial on the basis of one sort of difference - Irishness - in contrast to responses to other sorts of difference indigenous people in former settler colonies. ${ }^{2}$ Referring to RCS's own policy in his letter to the then RCS President Bernard Ribeiro on 28 Dec 2007, Brennan situated the case of Byrne directly in relation to the wider practices and ethics of indigenous repatriation that had recently emerged, writing that:

I am asking for the return of Mr Byrne's remains, for burial at sea. I request that the same courtesy be extended to the remains of this Irish person that have been previously extended to the indigenous inhabitants of North America, Australia and 
New Zealand. Accurate geographical provenance exists as Mr Byrne is Irish, and the wishes of Mr Byrne are not contravened as he wished to be buried at sea. (Brennan $2007 \mathrm{np})$.

This reference to equity of treatment is also emphasised in the letters sent in support of Brennan's case by Michael Ring, the Irish TD (Member of Parliament) for Brennan's constituency in Co. Mayo, to Margaret Hodge, then Minister of State for the Department of Culture, Media and Sport, and to the RCS. The case is subsequently made not simply in terms of equality of treatment but more directly in terms of racial or ethnic discrimination. Having received a response to his letter that set out the Hunterian case for continued retention and display, Brennan wrote again in October 2008 asking:

How does the Royal College of Surgeons justify their stance on refusing my request for the return of Mr. Byrne's remains to Ireland for burial, in relation to: i. The Race Relations Act. i.e. the less than favourable treatment of those who are Irish in comparison to the manner in which the College have previously treated those of North American, Australian and New Zealand origin.

ii. The Statutory duty to promote race equality which is imposed on the Royal College of Surgeons (Brennan 2008).

In the absence of a genealogically verified claimant, this turn to the question of racial equality requires making the skeleton stand for a deceased Irish person rather a person with rights as an individual, who can thus be spoken for not by descendants but by those in a wider national community of shared descent, and whose remains are not only disrespectfully on display but also not at home in their country of origin.

Making the remains Irish, however, involves the intersection of different postcolonial political relations, both geographically extended and proximate. The growing public awareness in Europe of the political agency of Australian and other indigenous groups in pursuing repatriation has contributed to concerns about the place of the remains of Charles Byrne. However, the treatment of his remains suggest a degree of insensitivity to the particular post-colonial dimensions of this case in the past by those in positions of English institutional power and in some strands of the British press. The Hunterian Museum curators responded to the negative publicity surrounding the 
controversy in 2013 by commissioning and installing a life size wax head and shoulders reconstruction of him to accompany the skeleton. The stated intentions were medical, educational and scientific and included the aim 'to enhance the reputation of the RCS' in these domains. This public relations exercise aimed to convey a more respectful and less objectified approach to him and his remains by 'enhancing the record of Charles Byrne's remains' (RCS 2013b). Yet the panel of text accompanying the skeleton evokes English colonial discourses of Irish primitivism by including the description of him by an English surgeon as 'an ill-bred disagreeable beast'. For Brennan and other Irish campaigners and commentators the growing sensitivity towards the appropriate treatment of the remains of indigenous groups contrasts sharply with the treatment of his remains and suggests that distinctions are being made between the treatment of indigenous and other human remains (McNally 2008; Ní Fóghlúdh 2012; O’Toole, 2009). Byrne has been afforded some personhood by the museum but his remains continue to be defined primarily as a pathological specimen.

In response to Brennan's appeals the Hunterian insisted that their position was based on equity of treatment rather than ethnic discrimination, and reiterated their case for the scientific and historical value of the remains. Indeed, it was stated that in contrast to indigenous remains the geographical origins of these remains were irrelevant to their collection and therefore irrelevant to the case for their removal: it was the specific gathering of indigenous remains to study racial difference that makes them now 'not considered directly irrelevant to a collection originally formed specifically for the purpose of improving medical science' and that informs positive responses to repatriation claims (Chaplin, 2009). In contrast, it is the medical rather than racial interest in Byrne that informs the retention of his remains. Simon Chaplin, then director of the Hunterian Museum was concerned to make clear in his message to Mark Caldon of the Cultural Property Unit of the DCMS that:

Our position is that there is no prejudice in the treatment of European and nonEuropean remains: our policy is that each claim will be considered on its merits. [...] In the case of Mr Brennan's claim, we gave due consideration to his case despite the fact that there was no claimed familial relationship, so it is our feeling that we have given equitable treatment in line with DCMS guidelines. The decision to retain the skeleton was made on the balance of evidence available to the Board, who felt that 
the remains' scientific, medical and historical significance were sufficient to justify the retention of the skeleton despite Mr Brennan's evident and sincere desire to see it returned. The ethnicity and/or nationality of Byrne and Mr Brennan were entirely incidental to this process - the skeleton is retained primarily because of its significance as a case of pituitary gigantism, not because of Byrne's nationality, and Mr Brennan's request was given the same serious consideration that an individual request from a UK citizen (or a citizen of any other country) would have received (Chaplin $2008 \mathrm{np}$ )

Yet, the 'ethnicity and/or nationality of Byrne' is not incidental to the wider interest in the case and recent representations of Byrne's life. These include the BBC Northern Ireland documentary Charles Byrne, the Irish Giant (2011) which explores his rural upbringing in Co. Tyrone and Hilary Mantel's novel The Giant, O Brien (1998) in which he represents an Irish culture of story telling, folk knowledge and classical learning in contrast to the utilitarian science of the enlightenment, thus challenging traditional antiIrish portrayals of Irish barbarity and English civility.

Indeed the internal correspondence on requests for reburial of the remains suggests that the College envisaged the likely involvement of the Irish state in future calls for their reburial. The Irish state is also deemed to be the most appropriate authority to give them 'a dignified and long overdue burial at sea' by the Free Charles Byrne campaign group (http://freecharlesbyrne.com/CAMPAIGN.html). However, the potential return of the remains are complicated by the historical and contemporary political geography of the island. In his life Byrne was a citizen of a state governed by a parliament in Dublin under the authority of the British crown; his childhood home in rural Co. Tyrone is now in Northern Ireland. If Byrne is imagined in terms of his membership of an Irish national community of shared descent that encompasses both Northern Ireland and Ireland, then the Irish state might be considered to have a role in deciding upon the right place for the remains. But if Byrne's final resting place is envisaged more specifically as his place of birth and upbringing, then it could be argued that is not a matter for another state but matter for the UK government, or the Northern Ireland Assembly. Byrne's desire to be buried at sea potentially avoids the issue of fixing a place for burial, though it has been argued that this reflected his desire to avoid his body being found by Hunter and that in 
usual circumstances he would have wanted to be laid to rest by burial in the ground in his place of birth and upbringing (Milligan 2012).

Indeed the idea of local or regional belonging and collective identity is a significant second scale of relatedness evoked in recent considerations of the case. While the calls for this reburial broadly position Charles Byrne as Irish and thus as part of the wider national community of shared descent, other approaches emphasis a more specific regional origin. Film-maker Ronan McCloskey's interest in making Charles Byrne, the Irish Giant, was prompted by being from the same area as Byrne in Co. Tyrone and 'fascinated by the number of actual giants in the area, and by the way they figured in Irish folklore not as freaks, but as kings, seers and poets' (Parry, 2011, p. 14). Shared local origin has also led some journalists to take up the case (McDowell 2012). But local commonality and regionality have a complex relation to the politics of identity and difference in this context. Northern Ireland can be understood in terms of an overarching regional identity and as a geography of ethno-national segregation. The local can be understood both as a source of shared identity and experienced and structured in terms of a micro-geography of division (Nash 2005b). Culture and heritage can be understood as both shared and diverse, and as divided and divisive. Given his Catholic background, Byrne could be remembered as part of a distinctly national Catholic community. Instead, he is one of the few historical figures that are not viewed the cultural property of one 'side'. Northern Irish children hear stories about 'Charlie', a 'Tyrone man' as part of a shared regional heritage. Thus Lindy McDowell writing in The Belfast Telegraph in 2013 called on Northern Irish 'public representatives' of both sides of the political divide to take up the case:

Poor tortured Charles Byrne wanted to be buried at sea because he saw that as the only place where his body would be safe. After all these years isn't it time we mounted a full-on determined campaign to have this gigantic betrayal of this gentle man who was one of our own finally put right? Charles Byrne - bring him home. (McDowell 2013)

A public undivided by ethnic-nationalist categories is being called upon to speak for Byrne 'as one of our own' and to 'bring him home'. Similarly, the Charles Byrne, the Irish Giant, documentary acknowledges his Catholic background but within an idea of a 
northern Irish past of cultural fusions and local identities. It features the form of Irish that was spoken by Byrne which was a fusion dialect of East Ulster Gaelic from Scottish settlers and East Ulster Irish.

A more intensely local belonging has also been evoked for Byrne's remains. Thomas Muinzer, a legal academic who has been a prominent advocate for the burial of the remains, argues that those whose wishes should be counted in this case are the people of Northern Ireland, most of whom, he claims, feel a 'marked sense of cultural affinity towards Byrne' $(2013,36)$. More specifically, he argues that stories of Byrne's life 'form an apparently continuous oral tradition that may stretch back as far as Byrne's own lifetime' in the village where he lived. The oldest people there recall playing as children on a local site known as 'the Giant's grave' which was a raised area in woodland 'where Byrne was said to have laid on his back and been 'drawn around' in the soil. It is remembered as being visited and tended until it was destroyed in the late 1960s or early 1970s. For Munzier, Byrne's wish to be buried there 'occupies a real and heartfelt place in the continuous folk narrative of Byrne's native homeland'. The depth of folk knowledge and local feeling, he argues, supports the case for making the burial of the remains as close as possible to the site of the Giant's Grave (Muinzer 2013,40). This is a microlocalization that envisages the skeleton being buried in the earth that Byrne lay upon or as close to it as possible. The local community, though identified as Northern Irish, are not differentiated according to ethno-religious background. Byrne, his remains, the people who remember him, share local belonging.

\section{Biomedical relations}

However, ideas of shared regional heritage and shared ancestry are also being articulated in arguments for the retention of the remains because of their biomedical value. This is based on the authority of new relatives and a new community of relations whose relatedness is both a scientific and socio-cultural product, made through a particular mix of biomedical research, film-making, media reporting and museum practice. The broadcasting of the documentary Charles Byrne, the Irish Giant in January 2011 was timed to closely follow, but not prempt, the publication of a research paper in which the genetic analysis of the remains of Charles Byrne are used to explore local patterns of ancestry and genetic inheritance in Northern Ireland (Chahal et al 2011). The research was led by endocrinologist Márta Korbonits of the Barts and London School of Medicine who 
collaborated with McCloskey in the making of the documentary, and facilitated by the Hunterian Museum who gave permission for genetic material to be extracted from one of Byrne's teeth. It originated in her observation that four families in a cohort of 140 families with familial isolated pituitary adenomas (FIPA) shared relatively close geographical origins in a region of Northern Ireland, and her curiosity about whether Byrne had the same mutation in a specific gene - the aryl hydrocarbon-interacting protein gene $(A I P)$ - that had already been established as the cause of FIPAs that cause gigantism and related conditions.

This suggested two interrelated research questions, one about Byrne's genome and one about ancestral relatedness. The aim of the study which followed was thus to explore 'the possibility that an $18^{\text {th }}$ century giant from Northern Ireland (the index patient whose skeleton is preserved), and the four Northern Irish families we identified inherited the same mutation from a common ancestor' $(2011,45)$. The aim was not simply to identify the mutation that caused his gigantism but to explore ancestral relatedness between the four Northern Irish patient families and Byrne. It was found that Byrne did have the same mutation as that of the four patient families, that he and they shared descent from an ancestor with the founding mutation 57 to 66 generations (1425 to 1650 years) ago, and that the same 'mutation responsible for this predisposition persists in the contemporary population of Ireland' $(2011,49)$.

Charles Byrne is figured in different ways in the scientific and popular making of this account of ancestral relations. The New England Journal of Medicine protocols of patient anonymity mean that Charles Byrne became an unnamed 'index patient' within its pages even though this anonymity is fragile within the paper as references to previous studies name him. It is also limited to it since the publicity for the paper and its widespread reporting centres on the analysis of his remains, its value to biomedical understanding and his shared ancestry with the Northern Irish patient families. However, the identification of a set of patients and families with the condition, or carrying the inherited mutation in Northern Ireland preceded and did not depend on the analysis of Byrne's remains. The finding that Byrne had the specific mutation and shares ancestry with contemporary people with the condition in Northern Ireland is not essential to the epidemiological work of identifying the geographical pattern of the occurrence of the mutation or to screening and treatment programmes. This is recognised in several calls for the burial of Byrne's remains that challenge the argument for the biomedical 
usefulness of their retention (Power, 2011, 37). The analysis of Byrne's remains appears to have been undertaken more as a matter of historical interest in Byrne's case in itself and the genealogical connections between Byrne and living people in the region from which he came, than for any direct biomedical application.

However, these newly established ancestral connections and the claim that the research demonstrates the scientific value of retaining the remains have become incorporated into the case for their retention. Though a familial or ancestral connection is usually the grounds for supporting claims for repatriation, here a newly discovered or, indeed, scientifically derived, ancestral connection gives authority to arguments for the continued retention of the remains. In response to the call for the burial of the remains by legal academics Len Doyal and Thomas Muinzer published in the British Medical Journal (BMJ) in 2011, Samuel Alberti, then Director of the Hunterian Museum, and representing the views of the Trustees of the Hunterian Collection, reiterated the longstanding argument for the continued potential benefit to be gained by keeping the remains for future scientific analysis. But he also argued that the study both demonstrates the potential biomedical benefit of the retention of the remains and, most significantly, establishes a community whose rights to determine the treatment of the remains should be recognised on the grounds of shared ancestry. For Alberti:

suggestions that all possible scientific benefit has been gleaned is not shared by researchers in relevant fields. Benefits include not only tangible clinical outcomes but also the identification of shared genes between Byrne and living communities. Among these are individuals who live with the same condition, who have requested that the skeleton remain on display. Given their shared ancestry with Byrne, particular credence has been given to these individuals' wishes. [...] Doyal and Muinzer's case is compelling. So too, however, is the argument that in accordance with the wishes of genetically connected individuals, Charles Byrne's remains be retained to advance our understanding of rare conditions and to benefit contemporary communities.' (Alberti, 2012).

The idea of genetic connection between Byrne and 'contemporary communities' through 'shared ancestry' established through the study is crucial to the claim that the wishes of individuals within this newly established community of shared descent should be 
respected. However, there is no evidence to suggest that the families carrying the AIP mutation in Northern Ireland cohere as a biosocial community of interest through their shared experience of the genetic condition, genetic disposition or patient advocacy and activism. The Familial Isolated Pituitary Adenoma Patients group website (www.fipatientcs.org) is a forum established by Márta Korbonits to support patients, inform doctors and foster greater awareness, better screening and identification of the condition. It features her research but does not represent a community who articulate a collective position on the Byrne case. Alberti's reference to 'contemporary communities' is based on several patient families who attended an event at the Hunterian Museum in November 2011 featuring the results of the genetic study, and who support the retention of the remains. One patient has come to represent these 'contemporary communities' because of his willingness to articulate his own perspective and these patient families' views on the value of retaining the remains. Brendan Holland, who comes from the same region in Northern Ireland as Byrne and has had a long term relationship with the Department of Endocrinology at Barts having been treated there for his condition as a young man, has come to occupy a position as spokesperson for this community and for Byrne. His support is important in the Hunterian's arguments about the retention of the remains:

Professor Korbonits' work vividly demonstrates the rich potential of historical human remains to advance our understanding of rare conditions and to benefit contemporary communities. Specifically, the work established the genetic connection between Byrne and living individuals with the condition including Brendan Holland. While this is not a direct genealogical connection, in the absence of any closer living relatives Mr Holland's explicit support of the retention and display of Byrne's remains is highly relevant (Alberti, 2011).

Brendan Holland collaborated with Ronan McCloskey's in making Charles Byrne, the Irish Giant and featured within it and later in a short film produced as supplement for the BMJ in December 2011. Anonymised extracts from his presentation at the museum event at were incorporated into the museum panel entitled 'Giant Genes' to accompany the remains that was revised in 2013: 'Byrne's body has yielded us vital information in the 
understanding of this condition', said one of the patients, 'personally, I find the revelation that the condition is genetic a source of great comfort'.

The Hunterian emphasis on Holland as a 'genetically connected individual' is shaped by the greater institutional and public awareness of the deep significance of broad ancestral relatedness in the repatriation of non-European indigenous remains. However, his status as spokesperson for Charles Byrne is not uncontested. For Doyal and Muinzer, his relatedness does not meet the model of familial closeness in Hunterian and wider policy on who has authority over human remains nor does it override the known wishes of the deceased. They argue that 'the fact that individuals have been discovered to have the same gene mutation as Byrne's neither legally nor morally gives them the status as relatives'. They responded to Alberti in the $B M J$ in this way:

when a person dies intestate, as was the case with Byrne, intestacy law assigns a 'duty to bury' to a set hierarchy of relatives. Such law admits conventional familial relatives, not persons with shared ancestry predicated on distant genetic connections. The moral reasoning behind the law seems clear enough.

If so, persons who are currently living, and who have been shown to share a genetic mutation with Byrne that stems from a 'common ancestor' who lived up to a potential 3750 years ago, can neither legally nor morally pronounce upon the matter of Byrne's remains with any more authority than any other member of the general public. In the case of Byrne, as far as we know, only one person sharing the gene mutation has come forward publically in favour of retaining the present exhibit. The views of this person have insufficient moral and legal weight to counter significant public agreement (e.g. in the poll conducted by the $B M J$ ) that Byrne's remains ought to be buried at sea or at least withdrawn from public display (Doyal and Muinzer 2012).

As they highlight, according to the strict logics of genealogical relatedness, Brendan Holland is not more ancestrally connected to Byrne than thousands of others. Since the common ancestor is so far back in time, and only one among many that could be identified between people in a wider survey of relatedness, Byrne could be genetically nearer or as near to thousands of others in Northern Ireland, Ireland and beyond if this was explored through wider surveys of genetic diversity. As is often the case in similar 
studies of genetic relatedness, an account of a shared ancestor produces an idea of distinctive ancestral connections within what would be a genealogical tangle of shared ancestry if viewed more widely. In this case, it is used to produce an idea of a distinctive degree of genetic connection that validates a position of authority in discussions of what should be done with the remains.

The point in following this making of relatedness through biomedicine, the media and the museum, is not, however, to undermine this or to simply set it against models of more 'authentic' and unmediated forms of kinship. If relatedness is understood as not simply genealogical or genetic but practiced and performed then the scientific making of relatedness can be seen as part of, rather than necessarily opposed to, the social practice of kinship, albeit working with different epistemologies and forms of power. Though the genetic studies contrive a distinctive relatedness out of more generalised shared ancestry, once they have done so relatedness is also made through how that genetic connection is performed and practiced socially and culturally. Furthermore the relatedness being foregrounded by Holland, Alberti and others is not only genetic or genealogical but also based on a shared experience of a genetically inherited condition. For Holland it is not ancestry alone but a connection based on greater understanding of Byrne's own suffering that informs his position, even given the differences in their experience. Holland is deeply appreciative of the care he has received and supports biomedical research for the advances in care that may follow and argues that Byrne would want his body to be available to biomedical research if he knew the benefit of the research. However, it is the ancestral connection produced through genetic analysis that validates his position as spokesperson for Byrne and for the 'living community' and initiates his doing of kinship with Byrne.

This kinship is not only mobilised in debates about whether the remains of an individual should be held and on display in a museum; it is also entangled in the making of a regional and local geography in mid-Ulster through medicine, myth and memory. The case of Charles Byrne is central to but also subsumed what is more a matter of reviving and creating knowledge than an unbroken continuity of local knowledge as in Muinzer's argument for the natural place for the remains. For Márta Korbonits, Ronan McCloskey and Brendan Holland, the Byrne case is part of wider efforts to uncover and foster knowledge of the regional occurrence of a medical condition. Exploring the relationship between Irish folklore traditions of giants, local history and the prevalence of gigantism 
in the region and acknowledging hidden and overlooked histories of suffering through the condition is central to McCloskey's interest in the case (Personal communication January 2017). Addressing suffering is also central to Márta Korbonits' effort to establish the regional epidemiology of the condition in Northern Ireland. The research on Byrne has been a key device in enabling her to establish the geographical concentration of carrier families in subsequent research and to improve diagnosis and early and effective treatment for patients with the condition. But it is secondary to the fundamental objectives of her research and clinical work. Lack of awareness of the pattern of local and familial inheritance, she argues, has meant late diagnosis or misdiagnosis and the failure to test families of patients for the condition. Her aim is to have 'no more giants'. The Charles Byrne research helped her to access patient samples in Northern Ireland and Ireland, to publish in a prestigious journal, and through the wide publicity it attracted, gain more funding, develop her international network of clinicians, find and treat more patients and screen their family members. The prevention of suffering drives her research: 'It starts with the patients and ends with the patients. Charles Byrne is just an interesting historical story in between' (Personal communication Jan 2017).

But other historical stories are also being uncovered through the epidemiological research. The research paper published in 2016 which reported the work led by Márta Korbonits mapping the localized pattern of the genetic mutation associated with genetic pituitary disease which caused gigantism in a small region in mid-Ulster included two photographs described as 'new evidence of historical Irish giants' (Radian et al, 2016, p.3). Both record the arrival of an emigrant from mid-Ulster, one from Garvagh arriving in Canada in 1918 and the other arriving in Western Australia in 1910, showing signs of gigantism and photographed for this reason. The photograph of the Canadian immigrant was brought to the research team who were collecting samples from the public in a local supermarket car park in mid-Ulster (Radian and Herincs 2013) by a participant who realised that her grandfather's uncle must have suffered from the condition which caused his death shortly after his arrival in Canada. The work of identifying the pattern of family inheritance and local incidence in mid-Ulster and fostering its use for better diagnosis and family screening to help patients is thus also uncovering personal, family, local, and diasporic accounts of those who suffered in the past. Charles Byrne was one of many. 


\section{Conclusion}

It is likely that careful curatorial decisions will be made about whether the remains of Charles Byrne retain their prominent place in the museum in future since this has clearly prompted people to act to contest both their retention and display. ${ }^{3}$ Tracing the ways they have done so demonstrates the differentiated and contingent rather than inherent or universal agency of human remains (Crandall and Martin, 2014; Arnold, 2014). The specific materiality of these remains shapes their particular agency since they stand for a whole person in a more than symbolic sense: the skeletal remains are intact, articulated and displayed upright in their glass case, rather than buried horizontally 'at rest'. Unlike a vial of human genetic material, for example, whose symbolic power derives from its representation in words and images, these remains denote the living body directly in terms of shape and form. Their agency is intensified by their location and status as an exhibited medical specimen which moves people to act to contest or defend this, and in doing so make relations for Charles Byrne.

Bringing a focus on geographies of relatedness to this case demonstrates the powerful purchase of ideas of shared ancestry and ancestral origins across a range of social domains, knowledge making practices and scales. Making kinship to and with human remains involves different models and geographies of relatedness that draw on and rework wider understandings of collective identity and belonging. The particular geographies of relatedness that are evoked in one context are not, however, isolated from those that matter in another. Arguments about these remains were informed by the way in which relatedness works in the repatriation of indigenous remains: broad communities of shared ancestry can assert an ancestral relation and thus make a case for the appropriate treatment of their ancestors' remains.

This suggests an intersecting postcolonial geography of repatriation. The practices, policies and politics of the repatriation of ancestral remains that connect museums in the UK to museums and indigenous groups in New Zealand, Australia and Hawaii inform how the particular, proximate and intimate postcolonial Irish-British relations play out, both shaping the claims that are made and highlighting the nature of those relations. Charles Byrne's remains are not being mobilised for overtly political ends (Verdery 1999), but arguments about them illuminate the nature of these postcolonial relations. A policy framework that cannot accord Byrne's remains indigenous status nor 
engage with arguments about their ethnic or national origin suggests a model of postcoloniality that is premised on both geographical distance and ethnic difference between the former colony and former colonial power. As in arguments that resistance to acknowledging anti-Irish racism in the UK reflects the double demonization and disavowal of Irish ethnic difference, the origins of Charles Byrne are not seen as different enough to deserve the belated respect due to indigenous remains. The postcoloniality of the UK's relation to Ireland is characterised by limited awareness of that very postcoloniality. Yet the significance of ancestry in indigenous repatriation claims informs the work of the museum in making and making use of a new authoritative relative in Brendan Holland since that relationship can be argued to be more significant than a more generalized national relatedness. According his views authority, as representative of a 'living community', clearly reflects both how genetic as well as conventional relatedness is ascribed significance and specific sensitivities about respecting the views of indigenous communities in repatriating ancestral remains.

The biomedical making of relations through genetic estimates of shared ancestry, raises new questions about what sort of relatedness can legitimate claims over the right place for human remains. The genomic making of relations through shared ancestry via the analysis of ancient as well as contemporary DNA is always entangled with ideas of geographical and genealogical categories and communities - global, continental, national, regional, and local. This case of the analysis of human remains from the relatively recent past, but beyond immediate familial relatedness in generations close to the present, raises wider questions about the implications of the new genomic production of knowledge about the dead in relation to the complex issues of the posthumous rights of the dead (Holm 2001; Masterson et al 2007; Taylor 2014). This includes the implications of disclosure of information about them, and tensions between the wishes of the deceased and their families and the potential biomedical value of research using donated human remains (McGuiness and Brazier 2008). Furthermore, the production of relatedness to and with human remains through their genomic analysis has implications for how individuals may be interpellated into new senses of relatedness and newly defined as a relation. This is particularly the case when new groups are constituted as biosocial communities through 'top down' science rather than emerging through biomedical activism and/or shared experience of or susceptibility to inherited conditions. 
However, tracing the biomedical making of kinship through human remains is not to suggest that relatedness that is a product of their genomic analysis is fabricated in contrast to 'natural' kinship. As scientific accounts of shared ancestry diffuse into wider domains they become incorporated into other discourses of relatedness, gaining social, cultural and moral as much as scientific authority. Genomic models of relatedness become performative through the ways newly constituted relations shape actions and assertions of kinship that are positioned by others as morally significant. But this intensifies rather than diminishes the question of the ethical responsibility of scientists who use genomics to produce genealogical or historical knowledge and those in positions of institutional power who deploy those knowledges.

Yet, as this case also suggests, the making of kinship to and through human remains can involve a range of social actors and institutions with distinct and overlapping interests and intentions, personal, collective, clinical, historical, scientific, and the entanglement of discourses of memory, local history, biomedicine and genomics, and national, regional, local and also diasporic geographies of collective identity and experience. The place of Charles Byrne in national and local communities of shared descent can be evoked to argue for his return; more specific accounts of ancestral connections can be used to argue for the retention of the remains for the sake of biomedical advances in the diagnosis and treatment of his regional relatives. In this case the genomic reckoning of ancestral connection is counter-posed to broader accounts of relatedness, as well as to individual posthumous rights. The making of relatedness can involve socio-cultural-biomedical coalitions of individuals and institutions with different degrees and forms of agency and authority rather than subordination to scientific expertise. Yet, while genomic accounts are not all determining in these new entanglements of ancestry, anthropological genetics and biomedicine, they provide resources, especially when combined with institutional authority, in adjudicating between competing claims that are not equally distributed. The remains of Charles Byrne thus remain in an anatomical collection against, and in keeping with, the wishes of his many relations.

\section{Acknowledgements}


I am very grateful for the comments of two referees, to all those who shared their perspectives on this case with me and to Sarah Morton whose work has been important in the development of this paper.

\footnotetext{
${ }^{1}$ Most notably the US Native American Graves Protection and Repatriation Act (1990) was a significant development in shifts in archaeological and museological approaches to indigenous human remains. In the UK, the outcry that followed the revelation of hospital policies of keeping human remains, especially those of children, for medical research, that led to the passing of the Human Tissue Act (2004) have shaped museum practice and public sensitivity towards the retention and display of human remains.

2 Though the repatriation of the remains of Sarah Baartman (1790-1815) in 2002 from Paris to Hankey, South Africa and those of Julia Pastrana (1834-1860) from Oslo to Sinaloa, Mexico in 2013 who, like Byrne, were exhibited in life before their remains were exhibited (Bredekamp 2006; Garland-Thompson 2017) are likely to have contributed to public interest in this case, the comparison that Brennan uses is that of indigenous repatriation more broadly.

3 The Hunterian Museum is due to reopen in 2020 after redevelopment of the RCS.
}

\section{Reference list:}

Alberti S J (2011) rapid response to 'Why the Royal College of Surgeons should respect the wishes of the 'Irish Giant'" British Medical Journal, 18 November 2011.

Alberti S J (2012) rapid response to 'Should the skeleton of the “Irish giant" be buried at sea?' British Medical Journal rapid response, 10 February 2012.

Arnold B (2014) Life After Life: Bioarchaeology and Post-mortem Agency. Cambridge Archaeological Journal 24(3): 523-529. 
Bredekamp J (2006) The Politics of Human Remains: The Case of Sarah Bartmann. In:

Lohman J and Goodknow K (eds.) Human Remains and Museum Practice, Paris and London:

UNESCO, 25-32.

Brennan M (2007) Letter to Bernard Ribeiro, Royal College of Surgeons, 28 Dec 2007. RCS Archives.

Brennan M (2008) Letter to Bernard Ribeiro, Royal College of Surgeons, 8 October 2008. RCS Archives.

Ceasar RC (2016) Kinship across conflict: family blood, political bones, and exhumation in contemporary Spain. Social Dynamics 42(2): 1-18.

Chahal H S et al (2011) AIP Mutation in Pituitary Adenomas in the $18^{\text {th }}$ Century and Today. The New England Journal of Medicine 364: 43-50.

Chaplin S (2008) Email to Mark Caldon, Department of Culture, Media and Sport, UK Government from Simon Chaplin, Director of Museums and Special Collections, Royal College of Surgeons, 17 October 2008, RSC Archives.

Chaplin S (2009) Letter to Michael Brennan from Simon Chaplin, Director of Museums and Special Collections, Royal College of Surgeons, 24 April 2009, RSC Archives.

Charlier P (2014) Naming the Body (or the Bones): Human Remains, Anthropology/Medical Collections, Religious Belief, and Restitution. Clinical Anatomy 27(3): 291-295.

Crandall J P and Martin D L (2014) The Bioarchaeology of Postmortem Agency: Integrating Archaeological Theory with Human Skeletal Remains. Cambridge Archaeological Journal 24(3): 429-435.

Doyal L and Muinzer T (2011a), Why the Royal College of Surgeons should respect the wishes of "the Irish giant", British Medical Journal 343: 1290-1292 
Doyal L and Muinzer T (2012a) Byrne's body should disappear beneath the waves British Medical Journal letters 344: e550, 28 January.

Doyal L and Muinzer T (2012b) rapid response to comments on 'Should the skeleton of "the Irish giant" be buried at sea?' British Medical Journal 343 d7597: 1290-1292, 20 December.

Fforde C and Hubert J (2006) Indigenous human remains and changing museums ideology. In Layton R, Shennan S and Stone P (Eds) A future for archaeology. London: UCL Press, pp. 8397.

Gandsman, A (2012) The Limits of Kinship Mobilizations and the (A)politics of Human Rights in Argentina. The Journal of Latin American and Caribbean Anthropology. 17(2):193-214.

Garland-Thompson R (2017) Julia Pastrana, the "extraordinary lady". ALTER: European Journal of Disability Research, 11(1): 35-49.

Hallam E and Hockey J (2001) Death, Memory and Material Culture. Oxford: Berg.

Hallam E, Hockey J and Howarth G (1999) Beyond the Body: Death and Social Identity. New York: Routledge.

Hallam E (2010) Articulating Bones: An Epilogue. Journal of Material Culture 15 (4): 465-492.

Holm S (2001) The Privacy of Tutankhamen - Utilising the Genetic Information Stored in Tissue Samples. Theoretical Medicine 22 (5): 437-449.

Johnson K M and Paul K S (2016) Bioarchaeology and Kinship: Integrating Theory, Social Relatedness, and Biology in Ancient Family Research. Journal of Archaeological Research 24:75-123.

Krmpotich C (2010) Remembering and Repatriation: The Production of Kinship, Memory and Respect. Journal of Material Culture 15(2): 157-179. 
Krmpotich C, Fontein J and Harries J (2010) The substance of bones: the emotive materiality and affective presence of human remains. Journal of Material Culture 15(4): 371-384.

McDowell L (2012) Why It's Time To Give Derry Giant A Decent Burial The Belfast Telegraph, 19 January.

McDowell L (2013) Can our politicians give a tall story a happy ending The Belfast Telegraph, 14 February.

McGuiness S and Brazier M (2008) Respecting the Living Means Respecting the Dead Too. Oxford Journal of Legal Studies 28(2): 297-316.

McNally F (2008) An Irishman's Diary, The Irish Times, 10 September.

Ní Fóghlúdh, Sorcha, (2012) Return the human remains that are closer to home, Museums Journal, letters section, 112(01): 20.

Mantel H (1998) The Giant, O’Brien. New York: Holt.

Masterton M, Hansson M G, Höglund A T and Helgesson G (2007) Can the dead be brought into disrepute? Theoretical Medicine and Bioethics 28(2): 137-149.

Milligen S (2012) Should the skeleton of the "Irish giant" be buried at sea? British Medical Journal rapid response, 7 March 2012 http://www.bmj.com/content/343/bmj.d7597/rapidresponses

Morton S (2017) The legacies of the repatriation of human remains. PhD thesis, University of Oxford.

Muinzer T L (2013) A Grave Situation: An Examination of the Legal Issues Raised by the Life and Death of Charles Byrne, the 'Irish Giant'. International Journal of Cultural Property 20(1): 23-48. 
Nash C (2015) Genetic Geographies: The Trouble with Ancestry. Minneapolis: Minnesota University Press.

Nash, C (2005a) Geographies of Relatedness Transactions of the Institute of British Geographers 30: 449-462

Nash C. (2005b), Local histories in Northern Ireland. History Workshop Journal, 60: 45-68

O’Toole F (2009) Cultural treasures that are stolen goods. The Irish Times, 7 March 2009.

Parry V (2011) Land of giants: How a Georgian bodysnatcher and Irish folklore are helping to treat people with growth disorders. The Guardian. 11 January, 14.

Power M (2011) Irish giant should be buried, not gaped at. The Guardian, 22 January, 37.

Radian S and Herincs M (2013) 'Legends and Facts: Population Screening for AIP Mutuations in Northern Ireland', The Endocrinologist, Summer 2013, 108: 24-25.

Radian, S., et al (2016) Increased Population Risk of AIP-Related Acromegaly and Gigantism in Ireland. Human Mutation. 38(1): 78-85.

Restrepo, E, Schwartz-Marín, E and Cárdenas, R (2014) Nation and Difference in the Genetic Imagination of Colombia, in Peter Wade, Carlos López Beltrán, Eduardo Restrepo and Richardo Ventura Santos eds. Mestizo Genomics: Race Mixture, Nation and Science in Latin America, Durham and London: Duke University Press, 55-84.

Royal College of Surgeons (2013a) Museums and Archives Acquisition and Disposal Policy, Royal College of Surgeons, London.

Royal College of Surgeons (2013b) Charles Byrne Facial Reconstruction Project Report, Royal College of Surgeons, London.

Slatkin M and Racimo F (2016) Ancient DNA and human history. PNAS 113 (23): 6380-6387. 
Taylor J S (2014) Death, posthumous harm, and bioethics. Journal of Medical Ethics 40(9): 636-637.

Turnbull P and Pickering M (eds.) (2010) Long way home: the meanings and values of repatriation, New York and Oxford: Berghahn Books.

Verdery K (2000) The Political Lives of Dead Bodies: Reburial and Postsocialist Change, New York: Columbia University Press

Young C and Light D (2013) Corpses, dead body politics and agency in human geography:

following the corpse of Dr Petru Groza. Transactions of the Institute of British Geographers 38: 135-148. 